\title{
Disseminating research findings: what should researchers do? A systematic scoping review of conceptual frameworks
}

\author{
Paul M Wilson ${ }^{1 *}$, Mark Petticrew ${ }^{2}$, Mike W Calnan ${ }^{3}$, Irwin Nazareth ${ }^{4}$
}

\begin{abstract}
Background: Addressing deficiencies in the dissemination and transfer of research-based knowledge into routine clinical practice is high on the policy agenda both in the UK and internationally.

However, there is lack of clarity between funding agencies as to what represents dissemination. Moreover, the expectations and guidance provided to researchers vary from one agency to another. Against this background, we performed a systematic scoping to identify and describe any conceptual/organising frameworks that could be used by researchers to guide their dissemination activity.

Methods: We searched twelve electronic databases (including MEDLINE, EMBASE, CINAHL, and PsycINFO), the reference lists of included studies and of individual funding agency websites to identify potential studies for inclusion. To be included, papers had to present an explicit framework or plan either designed for use by researchers or that could be used to guide dissemination activity. Papers which mentioned dissemination (but did not provide any detail) in the context of a wider knowledge translation framework, were excluded. References were screened independently by at least two reviewers; disagreements were resolved by discussion. For each included paper, the source, the date of publication, a description of the main elements of the framework, and whether there was any implicit/explicit reference to theory were extracted. A narrative synthesis was undertaken.

Results: Thirty-three frameworks met our inclusion criteria, 20 of which were designed to be used by researchers to guide their dissemination activities. Twenty-eight included frameworks were underpinned at least in part by one or more of three different theoretical approaches, namely persuasive communication, diffusion of innovations theory, and social marketing.

Conclusions: There are currently a number of theoretically-informed frameworks available to researchers that can be used to help guide their dissemination planning and activity. Given the current emphasis on enhancing the uptake of knowledge about the effects of interventions into routine practice, funders could consider encouraging researchers to adopt a theoretically-informed approach to their research dissemination.
\end{abstract}

\section{Background}

Healthcare resources are finite, so it is imperative that the delivery of high-quality healthcare is ensured through the successful implementation of cost-effective health technologies. However, there is growing recognition that the full potential for research evidence to improve practice in healthcare settings, either in relation to clinical practice or to managerial practice and decision making,

\footnotetext{
* Correspondence: paul.wilson@york.ac.uk

${ }^{1}$ Centre for Reviews and Dissemination, University of York, YO10 5DD, UK Full list of author information is available at the end of the article
}

is not yet realised. Addressing deficiencies in the dissemination and transfer of research-based knowledge to routine clinical practice is high on the policy agenda both in the UK [1-5] and internationally [6].

As interest in the research to practice gap has increased, so too has the terminology used to describe the approaches employed [7,8]. Diffusion, dissemination, implementation, knowledge transfer, knowledge mobilisation, linkage and exchange, and research into practice are all being used to describe overlapping and interrelated concepts and practices. In this review, we have used the term dissemination, which we view as a key
O

(c) 2010 Wilson et al; licensee BioMed Central Ltd. This is an Open Access article distributed under the terms of the Creative Commons Attribution License (http://creativecommons.org/licenses/by/2.0), which permits unrestricted use, distribution, and reproduction in any medium, provided the original work is properly cited. 
element in the research to practice (knowledge translation) continuum. We define dissemination as a planned process that involves consideration of target audiences and the settings in which research findings are to be received and, where appropriate, communicating and interacting with wider policy and health service audiences in ways that will facilitate research uptake in decision-making processes and practice.

Most applied health research funding agencies expect and demand some commitment or effort on the part of grant holders to disseminate the findings of their research. However, there does appear to be a lack of clarity between funding agencies as to what represents dissemination [9]. Moreover, although most consider dissemination to be a shared responsibility between those funding and those conducting the research, the expectations on and guidance provided to researchers vary from one agency to another [9].

We have previously highlighted the need for researchers to consider carefully the costs and benefits of dissemination and have raised concerns about the nature and variation in type of guidance issued by funding bodies to their grant holders and applicants [10]. Against this background, we have performed a systematic scoping review with the following two aims: to identify and describe any conceptual/organising frameworks designed to be used by researchers to guide their dissemination activities; and to identify and describe any conceptual/ organising frameworks relating to knowledge translation continuum that provide enough detail on the dissemination elements that researchers could use it to guide their dissemination activities.

\section{Methods}

The following databases were searched to identify potential studies for inclusion: MEDLINE and MEDLINE In-Process and Other Non-Indexed Citations (1950 to June 2010); EMBASE (1980 to June 2010); CINAHL (1981 to June 2010); PsycINFO (1806 to June 2010); EconLit (1969 to June 2010); Social Services Abstracts (1979 to June 2010); Social Policy and Practice (1890 to June 2010); Cochrane Database of Systematic Reviews, Cochrane Central Register of Controlled Trials, Cochrane Methodology Register, Database of Abstracts of Reviews of Effects, Health Technology Assessment Database, NHS Economic Evaluation Database (Cochrane Library 2010: Issue 1).

The search terms were identified through discussion by the research team, by scanning background literature, and by browsing database thesauri. There were no methodological, language, or date restrictions. Details of the database specific search strategies are presented Additional File 1, Appendix 1.
Citation searches of five articles [11-15] identified prior to the database searches were performed in Science Citation Index (Web of Science), MEDLINE (OvidSP), and Google Scholar (February 2009).

As this review was undertaken as part of a wider project aiming to assess the dissemination activity of UK applied and public health researchers [16], we searched the websites of 10 major UK funders of health services and public health research. These were the British Heart Foundation, Cancer Research UK, the Chief Scientist Office, the Department of Health Policy Research Programme, the Economic and Social Research Council (ESRC), the Joseph Rowntree Foundation, the Medical Research Council (MRC), the NIHR Health Technology Assessment Programme, the NIHR Service Delivery and Organisation Programme and the Wellcome Trust. We aimed to identify any dissemination/communication frameworks, guides, or plans that were available to grant applicants or holders.

We also interrogated the websites of four key agencies with an established record in the field of dissemination and knowledge transfer. These were the Agency for Healthcare Research and Quality (AHRQ), the Canadian Institutes of Health Research (CIHR), the Canadian Health Services Research Foundation (CHSRF), and the Centre for Reviews and Dissemination (CRD).

As a number of databases and websites were searched, some degree of duplication resulted. In order to manage this issue, the titles and abstracts of records were downloaded and imported into EndNote bibliographic software, and duplicate records removed.

References were screened independently by two reviewers; those studies that did not meet the inclusion criteria were excluded. Where it was not possible to exclude articles based on title and abstract alone, full text versions were obtained and their eligibility was assessed independently by two reviewers. Where disagreements occurred, the opinion of a third reviewer was sought and resolved by discussion and arbitration by a third reviewer.

To be eligible for inclusion, papers needed to either present an explicit framework or plan designed to be used by a researcher to guide their dissemination activity, or an explicit framework or plan that referred to dissemination in the context of a wider knowledge translation framework but that provided enough detail on the dissemination elements that a researcher could then use it. Papers that referred to dissemination in the context of a wider knowledge translation framework, but that did not describe in any detail those process elements relating to dissemination were excluded from the review. A list of excluded papers is included in Additional File 2, Appendix 2. 
For each included paper we recorded the publication date, a description of the main elements of the framework, whether there was any reference to other included studies, and whether there was an explicit theoretical basis to the framework. Included papers that did not make an explicit reference to an underlying theory were re-examined to determine whether any implicit use of theory could be identified. This entailed scrutinising the references and assessing whether any elements from theories identified in other papers were represented in the text. Data from each paper meeting the inclusion criteria were extracted by one researcher and independently checked for accuracy by a second.

A narrative synthesis [17] of included frameworks was undertaken to present the implicit and explicit theoretical basis of included frameworks and to explore any relationships between them.

\section{Results}

Our searches identified 6,813 potentially relevant references (see Figure 1). Following review of the titles and abstracts, we retrieved 122 full papers for a more detailed screening. From these, we included 33 frameworks (reported in 44 papers) Publications that did not meet our inclusion criteria are listed in Additional File 2, Appendix 2.

\section{Characteristics of conceptual frameworks designed to be used by researchers}

Table 1 summarises in chronological order, twenty conceptual frameworks designed for use by researchers $[11,14,15,18-34]$. Where we have described elements of frameworks that have been reported across multiple publications, these are referenced in the Table.

\section{Theoretical underpinnings of dissemination frameworks}

Thirteen of the twenty included dissemination frameworks were either explicitly or implicitly judged to be based on the Persuasive Communication Matrix [35,36]. Originally derived from a review of the literature of persuasion which sought to operationalise Lasswell's seminal description of persuasive communications as being

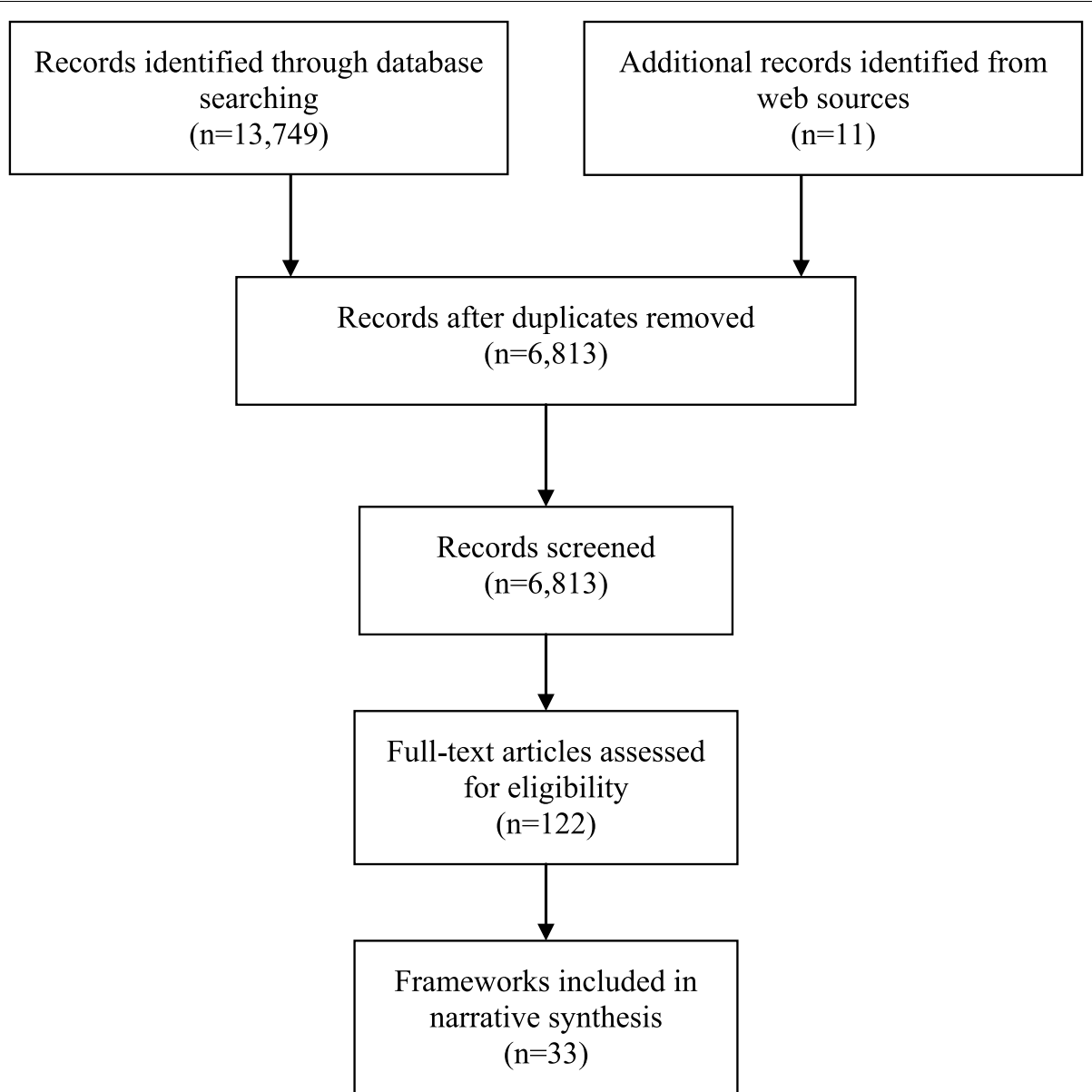

Figure 1 Identification of conceptual frameworks. 
Table 1 Conceptual frameworks designed for use by researchers

Develop a model to aid understanding about how new medical information in general and technology assessments in particular reaches practising physician and affects their practice The channels of communication The communication message The characteristics of the audience receiving the communication Explicitly based on McGuire's five attributes of persuasive communication.

Diffusion of innovations

Also sets framework in the context specifically The setting in which the communication is the innovation-decision process. received

Non

CRD $[17,18$

Presents a framework to be used by researchers seeking to promote the findings of a systematic review.

\section{Review topic}

Message

Audience

Source

Setting/context

Communication channels

mplementation of strategy

Feed back and evaluation

\section{Persuasive communication}

Revised version acknowledges McGuire's five attributes of persuasive communication. Implicit Winkler

\section{Diffusion of innovations}

2009 version also sets framework in the context of Diffusion of innovations specifically the Research (NCDDR)[19,38]

1996, 2001

To provide a knowledge base for strengthening the ways in which research results can be accessed and used by those who need them.

\section{individual responsible for creating the}

knowledge or product, and/or for
National Center for the Dissemination of Disability source (i.e., agency, organization, or

\section{Persuasive communication}

Not explicitly stated but four (source, message, audience, channel) of McGuire's five attributes persuasive communication evident.

content (message that is disseminated, that Diffusion of innovations

is, the new knowledge or product itself, as Also mentions Diffusion of Innovations; well as any supporting information or materials)

medium (i.e., ways in which the knowled

or product is described, 'packaged,' and

transmitted)

user (or intended user, of the information or product to be disseminated)

\section{Hughes $[20,60]$}

2000

Review the process of dissemination by those who carry it out, those who disseminate it and those who, potentially, make use of it. Examine current approaches to dissemination, considered their effectiveness, highlight obstacles to successful integration of research into practice and suggest a range of strategies to assist successful dissemination and implementation of research findings.

specifically the innovation-decision process

Reference to other included frameworks None

\section{Persuasive communication} persuasive communication evident. CRD

\section{Provide accessible summaries of research}

Keep the research report brief and concise Keep the research report brief and concise
Publish in journals or publications which are user friendly

se language and styles of presentation which engage interest

Target the material to the needs of the

Tadience

Extract the policy and practice implications of research

Tailor dissemination events to the target audience and evaluate them

Use the media

Use a combination of dissemination

methods

Be proactive

Understand external factors in original version that is explicitly derived from

innovation-decision process.

Reference to other included frameworks Winkler

Lomas

Greenhalgh in 2009 version

Hughes in 2009 version

Lavis in 2009 version

Communication effectiveness determined by five attributes. Appears to be first application of McGuire's matrix to the context of medical technology assessment. Argues that formal information dissemination followed by informal interaction with influential and knowledgeable colleagues likely to have most impact.

Framework for disseminating the findings of systematic reviews. Originally postulated that issemination effectiveness influenced by the sources of communications, media used, and audiences targeted.

Later versions acknowledge other elements of persuasive communications and expand into a three phase 'plan, develop, and implement process that assumes interaction with target audiences and consideration of setting in which messages received.

Review of literature suggests that some combination of four major dimensions of knowledge utilization that can help to strengthen dissemination efforts.

A detailed practical ten step-by-step quide for

researchers later produced. audience, channel) of McGuire's five attributes of systematic literature review and survey of key informants and organisations (including CRD). Authors suggest that active dissemination of research is often under resourced by research commissioners and researchers and that insufficient time and money are set aside when the original funding is considered

Five factors identified as contributing to effective dissemination: relevance, quality, accessibility, ownership and timing. List for researchers of factors that can help them disseminate research successfully.

Report also outlines suggestions for

commissioners, policy makers and practitioners for improving the effectiveness of research 


\section{Harmsworth [21]}

2001

To help educational development projects

engaged in the dissemination of new products,

materials and good practice in learning and

teaching to create an effective dissemination

strategy

\section{What is dissemination?}

What do we want to disseminate?

Who are our stakeholders and what are

we offering them?

When do we disseminate?

What are the most effective ways of

disseminating?

Who might help us disseminate?

How do we prepare our strategy?

How do we turn our strategy into an

action plan?

How do we cost our dissemination

activities?

How do we know we have been

successful?

2002

Presents an integrated dissemination model for social work and case study example to illustrate the practical application of the model

Field test the intervention
Assess market opportunities

and identify target system

Engage target system

Disseminate the intervention broadly

Gather system feedback and provide

ongoing consultation

\section{Persuasive communication}

Not explicitly stated but three (message,

audience, channel) of the McGuire's five

attributes of persuasive communication eviden

Reference to other included frameworks

None

Practical question based guide for educationa development projects.

States that it is based on experiences from over

100 educational development projects, in

particular, the Fund for the Development of

Teaching and Learning (FDTL) and the Teaching,

Learning Technology Programme (TLTP) and nnovations Fund.

\section{Scullion [23]}

2002

Examine examples of effective dissemination

strategies, provide insights and suggest pointers

for researchers, research students and others who

may be involved in dissemination.

\section{Jacobson [14]}

2003

To develop a framework that researchers and

other knowledge disseminators who are

embarking on knowledge translation can use to

increase their familiarity with the intended user

groups.

\section{avis [15]}

Provide an organizing framework for a knowledge transfer strategy and an overview of our understanding of the current knowledge for each of the five elements of the framework

\section{Source of the message}

Message characteristics

Medium selected to present the messag Target users

Five domains: $\quad$ None stated

The user group

The issue

The research

The researcher-user relationship

Dissemination strategies

\section{What should be transferred to decision} makers?

To whom should it be transferred? By whom should research knowledge be transferred?

How should research knowledge be transferred?

With what effect should research

knowledge be transferred?

\section{Persuasive communication Practical guide aimed at nursing researchers.}

Not explicitly stated but four (message, source, Refers to early descriptions of the CRD approach audience, channel) of McGuire's five attributes of [39].

persuasive communication

Reference to other included frameworks Carpenter

CRD

Reference to other included frameworks

None

Describes an integrated dissemination model for social work and provides an example to illustrate

its practical application (OutPatient Treatment In

ONtario Services -OPTIONS project)

Argues that diffusion of innovations and social

marketing address the important question of how

to put the products of research where they will

do the most good: into the hands of practicing

Author argues that current commitment

evidence-based practice will have limited impact

on practice and patient care until a similar

commitment to dissemination is evident at both

corporate and individual levels.

Novel framework derived from a review of the research utilisation literature and from the authors own experience.

Emphasises the importance of understanding user context. Each 'domain' provides researchers with a set of questions that can be used to aid the prioritisation of audiences and to develop and tailor relevant messages across user groups.

\section{Persuasive communication}

Organising framework and overview of literature relating to knowledge transfer strategies. Question format implicitly mirrors Lasswell's famous

description of the act of communications as 'Who description of the act of communications as Who
says what in which channel to whom with what effect' [37]. audience, source channel) (message attributes of persuasive communication Reference to other included framework None 


\begin{tabular}{|c|c|c|c|}
\hline $\begin{array}{l}\text { Farkas [24] } \\
2003 \\
\text { Describe a conceptual framework for the } \\
\text { dissemination and utilisation of information, long } \\
\text { with examples of its use }\end{array}$ & $\begin{array}{l}\text { Exposure strategies are those } \\
\text { dissemination methods that focus on the } \\
\text { goal of increased knowledge } \\
\text { Experience strategies focus on the goal of } \\
\text { increased positive attitudes towards the } \\
\text { new knowledge } \\
\text { Expertise strategies focus on the goal of } \\
\text { increased competence } \\
\text { Embedding strategies target consumers } \\
\text { tend to be personally focused }\end{array}$ & $\begin{array}{l}\text { Diffusion of innovations } \\
\text { Diffusion of innovations in that research has } \\
\text { concluded knowledge is not a 'thing to be sent } \\
\text { and received. Rather disseminating new findings } \\
\text { or information involves communicating through } \\
\text { 'certain channels over time among members of } \\
\text { a social system' } \\
\text { Reference to other included frameworks } \\
\text { NCDDR }\end{array}$ & $\begin{array}{l}\text { Authors suggest most dissemination practices are } \\
\text { not organized or planned to achieve } \\
\text { comprehensive impact. Role of framework is to } \\
\text { help researchers understand dissemination and } \\
\text { utilization as a series of active learning strategies } \\
\text { and to direct these at particular knowledge goals } \\
\text { and the needs of particular users. } \\
\text { Paper also presents examples of ' } 4 \mathrm{E}^{\prime} \text { ' use. }\end{array}$ \\
\hline $\begin{array}{l}\text { Economic and Social Research Council [26] } \\
2004 \\
\text { Provide advice on planning and prioritising } \\
\text { activities and includes a template you can use to } \\
\text { structure your own strategy. Aimed at research } \\
\text { directors but is applicable to any communications } \\
\text { exercise and should be useful to a wider group } \\
\text { of researchers. }\end{array}$ & $\begin{array}{l}\text { Checking perceptions } \\
\text { Setting objectives } \\
\text { Agreeing principles } \\
\text { Developing messages and branding } \\
\text { Prioritising audiences } \\
\text { Choosing channels } \\
\text { Planning activities } \\
\text { Estimating time } \\
\text { Estimating budget } \\
\text { Evaluating success }\end{array}$ & $\begin{array}{l}\text { Persuasive communication } \\
\text { Not explicitly stated but four (message, } \\
\text { audience, source as branding, channel) of } \\
\text { McGuire's five attributes of persuasive } \\
\text { communication } \\
\text { Reference to other included frameworks } \\
\text { None }\end{array}$ & $\begin{array}{l}\text { A detailed practical step-by-step guide on } \\
\text { planning and prioritising research communication. } \\
\text { Involves all key elements of McGuire's persuasive } \\
\text { communication matrix but also addresses more } \\
\text { practical issues such as timing and availability of } \\
\text { resources. } \\
\text { Available at: www.esrc.ac.uk/ESRCInfoCentre/CTK } \\
\text { communications-strategy/default.aspx }\end{array}$ \\
\hline $\begin{array}{l}\text { Canadian Health Services Research Foundation } \\
\text { [25] } \\
2004 \\
\text { List of Key elements that should be included in a } \\
\text { dissemination plan. Provide a good overview of } \\
\text { some of the most critical things that should be } \\
\text { considered }\end{array}$ & $\begin{array}{l}\text { Project overview } \\
\text { Dissemination goals } \\
\text { Target audiences } \\
\text { Key messages (contextualised) } \\
\text { Sources/messengers } \\
\text { Dissemination activities, tools, timing and } \\
\text { responsibilities } \\
\text { Budget } \\
\text { Evaluation }\end{array}$ & $\begin{array}{l}\text { Persuasive communication } \\
\text { Not explicitly stated but all (message, audience, } \\
\text { setting, source, channel) of McGuire's five } \\
\text { attributes of persuasive communication } \\
\text { Reference to other included frameworks } \\
\text { None }\end{array}$ & $\begin{array}{l}\text { Brief overview of key elements that should be } \\
\text { considered as part of a collaborative research } \\
\text { planning process. Involves all key elements of } \\
\text { McGuire's persuasive communication matrix but } \\
\text { also addresses more practical issues such as } \\
\text { timing and availability of resources. } \\
\text { Available at: } \\
\text { www.chsrf.ca/keys/use_disseminating_e.php }\end{array}$ \\
\hline $\begin{array}{l}\text { European Commission [27] } \\
2004 \\
\text { Aims to assist project coordinators and team } \\
\text { leaders to generate an effective flow of } \\
\text { information and publicity about the objectives } \\
\text { and results of their work, the contributions made } \\
\text { to European knowledge and scientific excellence, } \\
\text { the value of collaboration on a Europe-wide scale, } \\
\text { and the benefits to EU citizens in general. }\end{array}$ & $\begin{array}{l}\text { Defining key messages } \\
\text { Establishing target audiences } \\
\text { Selecting the appropriate modes of } \\
\text { communication } \\
\text { Tailoring information to the intended } \\
\text { outlets } \\
\text { Building good relationships with the } \\
\text { media } \\
\text { Evaluating results } \\
\text { Maximising the exposure of messages } \\
\text { Tapping useful Commission and other } \\
\text { external resources }\end{array}$ & $\begin{array}{l}\text { Persuasive communication } \\
\text { Not explicitly stated but three (message, } \\
\text { audience, channel) of McGuire's five attributes of } \\
\text { persuasive communication } \\
\text { Reference to other included frameworks } \\
\text { None }\end{array}$ & $\begin{array}{l}\text { Practical guide aimed at researchers in EU Sixth } \\
\text { (now seventh) Framework Programme projects. } \\
\text { Provides an outline of good practices to assist } \\
\text { researchers to generate an effective flow of } \\
\text { information and publicity about the objectives } \\
\text { and results of their work. } \\
\text { Focuses primarily on research communication via } \\
\text { mass media channels }\end{array}$ \\
\hline $\begin{array}{l}\text { Carpenter [28] } \\
2005 \\
\text { Designed to assist the Agency for Healthcare } \\
\text { Research and Quality (AHRQ) Patient Safety } \\
\text { grantees with disseminating their research results }\end{array}$ & $\begin{array}{l}\text { What is going to be disseminated? } \\
\text { Who will apply it in practice? } \\
\text { Through whom can you reach end users? } \\
\text { How you convey the research outcomes? } \\
\text { How you determine what worked? } \\
\text { Where do you start? }\end{array}$ & $\begin{array}{l}\text { Persuasive communication } \\
\text { Not explicit but four (message, audience, source, } \\
\text { channel) of McGuire's five attributes of } \\
\text { persuasive communication derived from Lavis } \\
\text { Diffusion of innovations } \\
\text { Reference to other included frameworks } \\
\text { NCDDR } \\
\text { Lavis }\end{array}$ & $\begin{array}{l}\text { Practical guide including six major elements } \\
\text { aimed at AHRQ patient safety researchers. Basic } \\
\text { premise is to provide a structure to what can be a } \\
\text { nebulous concept yet which researchers are } \\
\text { increasingly expected to respond. Emphasises } \\
\text { importance of engaging end users in planning } \\
\text { process. }\end{array}$ \\
\hline
\end{tabular}




\begin{tabular}{|c|c|c|c|}
\hline $\begin{array}{l}\text { Bauman [29] } \\
2006 \\
\text { Provide a six step framework for understanding } \\
\text { international approaches to physical activity } \\
\text { diffusion and dissemination. }\end{array}$ & $\begin{array}{l}\text { Describe the innovation, its rationale and } \\
\text { evidence base, and its relevance in an } \\
\text { international context; } \\
\text { Describe the target audience for } \\
\text { dissemination and the sequence, timing, } \\
\text { and formatting of dissemination strategies; } \\
\text { Define the international communication } \\
\text { channels for the innovation; } \\
\text { Determine the role of key policymakers } \\
\text { and sustainable partnerships that are } \\
\text { needed to implement the innovation at } \\
\text { different levels (local, state, national, } \\
\text { international); } \\
\text { Identify the barriers and facilitators of the } \\
\text { innovation in the international context; } \\
\text { and } \\
\text { Conduct research and evaluation to } \\
\text { understand the dissemination process. }\end{array}$ & $\begin{array}{l}\text { Diffusion of innovations } \\
\text { Application of Diffusion of Innovations in a } \\
\text { public health context } \\
\text { Persuasive communication } \\
\text { Not explicitly stated but three (audience, } \\
\text { channel, setting) of McGuire's five attributes of } \\
\text { persuasive communication } \\
\text { Reference to other included frameworks } \\
\text { None }\end{array}$ & $\begin{array}{l}\text { Authors emphasise that dissemination one part of } \\
\text { diffusion process. Much of framework based on } \\
\text { expert opinion and experiences. } \\
\text { Four case studies presented to illustrate aspects of } \\
\text { framework. Authors suggest that these share } \\
\text { some common elements, including strong } \\
\text { advocacy, good communications between key } \\
\text { individuals and institutions, and the presence of } \\
\text { shared values and population-level approaches. }\end{array}$ \\
\hline $\begin{array}{l}\text { Zarinpoush [31] } \\
2007 \\
\text { To provide a framework that is intended to help } \\
\text { non-profit organizations plan, conduct, and } \\
\text { evaluate efforts to transfer and exchange } \\
\text { knowledge with others }\end{array}$ & $\begin{array}{l}\text { Define the target audience } \\
\text { Preparing the message (Clear, Concise, } \\
\text { Consistent, Compelling, Continuous) } \\
\text { Selection of transfer method (s) } \\
\text { Messenger credibility } \\
\text { Evaluation of expected effects }\end{array}$ & $\begin{array}{l}\text { Persuasive communication } \\
\text { Not explicitly stated but } \\
\text { four (message, source, audience, channel) of } \\
\text { McGuire's five attributes of persuasive } \\
\text { communication } \\
\text { Reference to other included frameworks } \\
\text { Lavis }\end{array}$ & $\begin{array}{l}\text { Five key elements to consider when planning } \\
\text { knowledge transfer and exchange activity. States } \\
\text { elements derived from recent literature, including } \\
\text { Lavis. }\end{array}$ \\
\hline $\begin{array}{l}\text { Formoso [30] } \\
2007 \\
\text { To analyse the barriers to knowledge transfer that } \\
\text { are often inherent in the format of the } \\
\text { information communicated. Proposes a more } \\
\text { user-friendly, enriched format to facilitate the } \\
\text { translation of evidence-based information into } \\
\text { practice. }\end{array}$ & $\begin{array}{l}\text { Five dimensions for enhancing information } \\
\text { delivery: } \\
\text { Contextualization/enrichment } \\
\text { Validity/critical appraisal } \\
\text { Comprehensibility of data on clinical } \\
\text { benefits and harms } \\
\text { Applicability and relevance } \\
\text { Straightforwardness and appeal }\end{array}$ & $\begin{array}{l}\text { Social marketing } \\
\text { Reference to other included frameworks } \\
\text { None }\end{array}$ & $\begin{array}{l}\text { Describes five dimensions for enhancing } \\
\text { information delivery and argues that little } \\
\text { attention is focussed on the way clinical } \\
\text { information is constructed and communicated } \\
\text { and how it can be made more relevant, } \\
\text { acceptable and eventually 'got through' to } \\
\text { practitioners. } \\
\text { Social marketing techniques may help the } \\
\text { promotion of evidence-based knowledge. This } \\
\text { would entail systematically analysing and } \\
\text { addressing barriers to clarity and acceptability of } \\
\text { information, and offering a comprehensive and } \\
\text { critical look at its validity, biases and relevance. } \\
\text { However, paper does not fully describe or apply } \\
\text { the key features of a social marketing approach. }\end{array}$ \\
\hline
\end{tabular}


Table 1 Conceptual frameworks designed for use by researchers (Continued)

\section{Majdzadeh [32]}

2008

Provide a conceptual framework to identify

barriers and facilitators and design strategies to knowledge translation strategies to be used by organisations doing research
Five domains:

Knowledge creation considers the

characteristics of researchers and research

Knowledge transfer

considers resources and strategies

Research utilization considers the

characteristics of decision makers and

context of decision making;

Question transfer considers research

priorities and funders

Context of organization considers the

leadership system, policies, values, and

culture of the organisation doing research
None stated

Reference to other included frameworks

Jacobson

Lavis

\begin{tabular}{|c|c|c|c|}
\hline $\begin{array}{l}\text { Friese [33] } \\
2009 \\
\text { To identify what the cultural divides are between } \\
\text { researchers and policymakers and how social } \\
\text { scientists have bridged these differences by } \\
\text { careful attention to several pragmatic practices } \\
\text { for increasing research use in policymaking }\end{array}$ & $\begin{array}{l}\text { Conceptualize policy work, not as } \\
\text { disseminating information, but as } \\
\text { developing relationships } \\
\text { Take the initiative to contact policymakers } \\
\text { or policy intermediaries } \\
\text { Learn about the target policymaking } \\
\text { audience } \\
\text { Communicate research findings in ways } \\
\text { that meet policymakers' information needs } \\
\text { Use clear, careful language when dealing } \\
\text { with myths about vulnerable populations } \\
\text { Familiarize yourself with the policymaking } \\
\text { process } \\
\text { Provide a timely response to the questions } \\
\text { driving the policy debate } \\
\text { Learn how to approach policy work as an } \\
\text { educator rather than an advocate } \\
\text { Show respect for policymakers' knowledge } \\
\text { and experience } \\
\text { Be patient and self-rewarding in defining } \\
\text { success. }\end{array}$ & $\begin{array}{l}\text { Two-communities theory } \\
\text { Reference to other included frameworks } \\
\text { None }\end{array}$ & $\begin{array}{l}\text { Based around notion that the underutilisation of } \\
\text { research is down to a communication gap } \\
\text { between researchers and policymakers, who have } \\
\text { differing goals, information needs, values, and } \\
\text { language that are best thought of as a cultural } \\
\text { divide. } \\
\text { Ten recommendations derived from qualitative } \\
\text { interviews on the barriers and facilitators to } \\
\text { research communication with social scientists } \\
\text { working in family policy. }\end{array}$ \\
\hline $\begin{array}{l}\text { Yuan [34] } \\
2010 \\
\text { Present a conceptual framework and } \\
\text { propose a eight point strategy for improving the } \\
\text { dissemination of best practices by national quality } \\
\text { improvement campaigns }\end{array}$ & $\begin{array}{l}\text { Provide simple, evidence- based } \\
\text { recommendations } \\
\text { Align messages with strategic goals of } \\
\text { adopting organization } \\
\text { Use a nodal organizational structure } \\
\text { Engage a coalition of credible campaign } \\
\text { sponsor } \\
\text { Establish threshold of participating } \\
\text { organizations } \\
\text { Provide practical implementation tools } \\
\text { Create networks to foster learning } \\
\text { opportunities } \\
\text { Monitor progress and evaluate impact }\end{array}$ & $\begin{array}{l}\text { Diffusion of innovations } \\
\text { Builds on Diffusion of Innovations but with a } \\
\text { focus on active dissemination; planned efforts to } \\
\text { persuade targeted groups to adopt an } \\
\text { innovation } \\
\text { Reference to other included frameworks } \\
\text { Greenhalgh }\end{array}$ & $\begin{array}{l}\text { Authors recognise that dissemination impact } \\
\text { depends on contextual factors, including the } \\
\text { nature of the innovation itself, external } \\
\text { environmental incentives, and features of the } \\
\text { adopting organizations. They argue that although } \\
\text { important contextual considerations are outside } \\
\text { the control of disseminators, greater use of their } \\
\text { strategy is likely to promote more potent } \\
\text { campaign efforts, more effective dissemination, } \\
\text { and ultimately greater take-up of evidence-based } \\
\text { practices. }\end{array}$ \\
\hline
\end{tabular}

Friese [33]

have bridged these differences by

for increasing research use in policymaking meet policymakers' information needs Use clear, careful language when dealing with myths about vulnerable populations

Show respect for policymakers' knowledge and experience

\section{Yuan [34]}

propose a eight point strategy for imp improvement campaign

\author{
Use a nodal organizational structure \\ sponsor coalition of credible campaign \\ Establish threshold of participating \\ organizations \\ Monitor progress and evaluate impac
}

Practical Tehran University of Medical Sciences

(TUMS) framework

literature

Authors' suggest universities depend primarily on

the passive dissemination of knowledge.

They suggest the following strategies can make

knowledge translation more effective in

universities: defining and setting up of a system

to assess the knowledge translation cycle;

implementation and use of information

technology; identification and encouragement of

face-to-face interactions between researchers and

decision makers; exchanging knowledgeable

individuals among centres; creating mutual trust, a common language and culture for the creation of organizational knowledge; using important motivational tools in the university, using multidimensional methods for knowledge transfer

Based around notion that the underutilisation of research is down to a communication gap rearchers and policymakers, who have goals, information needs, values, and divide.

vecommendations derived from qualitative interviews on the barriers and facilitators to research communication with social scientists working in family policy. 
about 'Who says what in which channel to whom with what effect' [37]. McGuire argued that there are five variables that influence the impact of persuasive communications. These are the source of communication, the message to be communicated, the channels of communication, the characteristics of the audience (receiver), and the setting (destination) in which the communication is received.

Included frameworks were judged to encompass either three $[21,27,29]$, four $[15,20,23,26,28,31,38]$, or all five $[11,18,25]$ of McGuire's five input variables, namely, the source, channel, message, audience, and setting. The earliest conceptual model included in the review explicitly applied McGuire's five input variables to the dissemination of medical technology assessments [11]. Only one other framework (in its most recent version) explicitly acknowledges McGuire [17]; the original version acknowledged the influence of Winkler et al. on its approach to conceptualising systematic review dissemination [18]. The original version of the CRD approach $[18,39]$ is itself referred to by two of the other eight frameworks [20,23]

Diffusion of Innovations theory [40,41] is explicitly cited by eight of the dissemination frameworks $[11,17,19,22,24,28,29,34]$. Diffusion of Innovations offers a theory of how, why, and at what rate practices or innovations spread through defined populations and social systems. The theory proposes that there are intrinsic characteristics of new ideas or innovations that determine their rate of adoption, and that actual uptake occurs over time via a five-phase innovation-decision process (knowledge, persuasion, decision, implementation, and confirmation). The included frameworks are focussed on the knowledge and persuasion stages of the innovation-decision process.

Two of the included dissemination frameworks make reference to Social Marketing [42]. One briefly discusses the potential application of social and commercial marketing and advertising principles and strategies in the promotion of non-commercial services, ideas, or research-based knowledge [22]. The other briefly argues that a social marketing approach could take into account a planning process involving 'consumer' oriented research, objective setting, identification of barriers, strategies, and new formats [30]. However, this framework itself does not represent a comprehensive application of social marketing theory and principles, and instead highlights five factors that are focussed around formatting evidence-based information so that it is clear and appealing by defined target audiences.

Three other distinct dissemination frameworks were included, two of which are based on literature reviews and researcher experience [14,32]. The first framework takes a novel question-based approach and aims to increase researchers' awareness of the type of context information that might prove useful when disseminating knowledge to target audiences [14]. The second framework presents a model that can be used to identify barriers and facilitators and to design interventions to aid the transfer and utilization of research knowledge [32]. The final framework is derived from Two Communities Theory [43] and proposes pragmatic strategies for communicating across conflicting cultures research and policy; it suggests a shift away from simple one-way communication of research to researchers developing collaborative relationships with policy makers [33].

\section{Characteristics of conceptual frameworks relating to knowledge translation that could be used by researchers to guide their dissemination activities}

Table 2 summarises in chronological order the dissemination elements of 13 conceptual frameworks relating to knowledge translation that could be used by researchers to guide their dissemination activities [13,44-55].

\section{Theoretical underpinnings of dissemination frameworks}

Only two of the included knowledge translation frameworks were judged to encompass four of McGuire's five variables for persuasive communications $[45,47]$. One framework [45] explicitly attributes these variables as being derived from Winkler et al [11]. The other [47] refers to strong direct evidence but does not refer to McGuire or any of the other included frameworks.

Diffusion of Innovations theory [40,41] is explicitly cited in eight of the included knowledge translation frameworks [13,45-49,52,56]. Of these, two represent attempts to operationalise and apply the theory, one in the context of evidence-based decision making and practice [13], and the other to examine how innovations in organisation and delivery of health services spread and are sustained in health service organisations [47,57]. The other frameworks are exclusively based on the theory and are focussed instead on strategies to accelerate the uptake of evidence-based knowledge and or interventions

Two of the included knowledge translation frameworks $[50,53]$ are explicitly based on resource or knowledgebased Theory of the Firm [58,59]. Both frameworks propose that successful knowledge transfer (or competitive advantage) is determined by the type of knowledge to be transferred as well as by the development and deployment of appropriate skills and infrastructure at an organisational level.

Two of the included knowledge translation frameworks purport to be based upon a range of theoretical perspectives. The Coordinated Implementation model is derived from a range of sources, including theories of social influence on attitude change, the Diffusion of 
Table 2 Conceptual frameworks relating to knowledge translation that could be used by researchers to guide their dissemination activities

\begin{tabular}{llll}
\hline Author, Year, Aims & Dissemination elements & Theoretical foundations & Description/Comment \\
\hline Funk [44] & $\begin{array}{l}\text { Qualities of Research } \\
\text { (described as topic selection based }\end{array}$ & $\begin{array}{l}\text { None stated } \\
\text { Reference to other included }\end{array}$ & $\begin{array}{l}\text { Describes an approach devised by } \\
\text { the National Center for Nursing }\end{array}$ \\
$\begin{array}{ll}\text { To facilitate the use of research in } \\
\text { clinical settings by providing }\end{array}$ & $\begin{array}{l}\text { on literature reviews and surveys of } \\
\text { clinicians with criteria focussed on }\end{array}$ & None & Research to make research results \\
findings that are relevant and ready & $\begin{array}{l}\text { relevance, applicability and the } \\
\text { to use, in a form that maintains the }\end{array}$ & $\begin{array}{l}\text { perceived gaps between evidence } \\
\text { richness to practising nurses via a }\end{array}$ & topic focused conference and \\
monograph series.
\end{tabular}

richness of full research reports yet

and practice) is still understandable to the general reader.

Characteristics of the

communication (including use of non-technical language, emphasis on implications for practice and strategies for implementation). Facilitation of utilisation (provision of enquiry centre for implementation advice and to respond to requests for further information and feedback channel for researchers and practitioners)

Lomas[12,45] Dissemination elements within

1993

Presents a coordinated wider implementation model: implementation model that that seeks to shed light on The message
Its source

The communication channels dissemination processes and on best how to flow research findings into practice.
The implementation setting

\author{
Mixed \\ Argues that use of research in \\ Full model derived from models of practice may depend more on a \\ social influence, diffusion of \\ innovations, adult learning theory \\ and social marketing. \\ Persuasive communication \\ Four (source, setting, message, \\ channel) of McGuire's five attributes \\ of persuasive communication \\ evident (explicitly derived from \\ Winkler) \\ Reference to other included \\ frameworks \\ Winkler \\ change in researchers behaviour \\ than it does on practitioners- \\ research findings most likely to find \\ their way into practice when they \\ are synthesised, contextualised, \\ packaged to the needs of the end \\ user. \\ Wider model recognises the \\ external influencing factors on the \\ overall practice environment \\ including, economic resources, \\ legislation and regulation, \\ education, personnel as well as \\ public (media) and patient \\ pressures.
}

\begin{tabular}{ll}
\hline Dobbins[13] & Complex interrelationships \\
2002 & that exist among five stages of \\
To construct a comprehensive & innovation (knowledge, persuasion, \\
framework of research & decision, implementation and \\
dissemination and utilisation. & confirmation) and four types of \\
& characteristics (innovation, \\
& organization, environment and \\
& individual) as progression from \\
& research dissemination to research \\
& utilization occurs
\end{tabular}

\section{Diffusion of innovations}

Explicit application of Rogers

diffusion of innovations innovationdecision process

Reference to other included frameworks

None
Application of Rogers's innovationdecision process to health research dissemination and utilisation. Framework integrates concepts of research dissemination (knowledge, persuasion), evidence-based decision making (decision) and research utilisation

(implementation) within the innovations decision process of diffusion of innovations theory. Argues that the extent to which an individual or organisation becomes knowledgeable about new ideas is somewhat dependent on the dissemination strategies employed by health researchers

Authors state that dissemination and capacity exist within a broader social, political, economic context operating at micro, meso and macro levels

The framework posits that contextual factors act as mediators shaping the behaviours and values of individuals and organizations, innovations, and influencing the process and outcome of capacity building and dissemination. 
Table 2 Conceptual frameworks relating to knowledge translation that could be used by researchers to guide their dissemination activities (Continued)

Greenhalgh [47,57]

2004

Review of the literature on the spread and sustainability of innovations in health service delivery and organisation Develop and apply (in four case studies) a unifying conceptual model based on the evidence.
Planned dissemination elements within wider model: Address needs and perspectives of potential adopters Tailor different strategies to different groups Use appropriate messages Use appropriate communication channels

Undertake rigorous evaluation
Diffusion of innovations

Application of Diffusion of Innovations in a health service delivery and organisation context Persuasive communication Not explicitly stated but four (message, setting, audience, channel) of McGuire's five attributes of persuasive communication Reference to other included frameworks None

Formal dissemination programs, defined as active and planned efforts to persuade target groups to adopt an innovation are more effective if the program's organizers (1) take full account of potential adopters' needs and perspectives, with particular attention to the balance of costs and benefits for them; (2) tailor different strategies to the different demographic, structural, and cultural features of different subgroups; (3) use a message with appropriate style, imagery, metaphors, and so on; (4) identify and use appropriate communication channels; and (5) incorporate rigorous evaluation and monitoring of defined goals and milestones

\section{Green [48]}

2006

Review tobacco control dissemination experience to draw guidance for physical activity promotion
Push: strengthening science push by proving, improving, and communicating effective interventions for wide population use;

Pull: boosting demand, or market pull for interventions among consumers, and healthcare purchasers and policymakers Capacity: building the capacity of relevant systems and institutions to deliver them

\section{Diffusion of innovations}

Diffusion of Innovations used to assess how tobacco control lessons diffuse and apply to the field of physical activity Reference to other included frameworks None

Author's state dissemination encompasses the planned facilitation and acceleration of diffusion of innovations, transfer and utilization of knowledge, and implementation of the resulting adaptations in local circumstances. Author suggest lessons from tobacco control include the need for a funded mandate; the mass media to frame the public policy debate and to help undermine negative behaviour; the comprehensiveness of interventions at national and local levels to mutually reinforce each other; the need for systematic evaluation; the need for policy and funding to support programs; the need for coordinated programs to support individuals.

\begin{tabular}{|c|c|c|c|}
\hline $\begin{array}{l}\text { Owen [49] } \\
2006 \\
\text { Outline the main attributes of } \\
\text { Diffusion of Innovations and key } \\
\text { concepts to consider in the } \\
\text { dissemination and diffusion of } \\
\text { innovations to promote physical } \\
\text { activity }\end{array}$ & $\begin{array}{l}\text { Advocacy: identifying and } \\
\text { engaging key stakeholders } \\
\text { Increased funding to build the } \\
\text { evidence base to supply diffusion } \\
\text { and dissemination strategies and to } \\
\text { allow investigators to gain } \\
\text { experience with type of role } \\
\text { Implement surveillance systems to } \\
\text { track use of evidence-based } \\
\text { interventions }\end{array}$ & $\begin{array}{l}\text { Diffusion of innovations } \\
\text { Application of Diffusion of } \\
\text { Innovations in a public health } \\
\text { context } \\
\text { RE-AlM framework can be used to } \\
\text { determine the success and impact } \\
\text { of dissemination efforts } \\
\text { Reference to other included } \\
\text { frameworks } \\
\text { None }\end{array}$ & $\begin{array}{l}\text { Diffusion of innovations theory can } \\
\text { be applied to accelerate the rate of } \\
\text { diffusion specifically to promote } \\
\text { physical activity interventions. } \\
\text { Authors present two case studies } \\
\text { and argue that their success } \\
\text { illustrates the need for dedicated } \\
\text { field staff, product production, } \\
\text { marketing, and distribution. }\end{array}$ \\
\hline $\begin{array}{l}\text { Landry [50] } \\
2007 \\
\text { To determine the extent of } \\
\text { research transfer in natural sciences } \\
\text { and engineering among Canadian } \\
\text { university researchers; } \\
\text { to examine any differences } \\
\text { between various disciplines with } \\
\text { regard to the extent of transfer; to } \\
\text { examine the determinants of } \\
\text { research transfer }\end{array}$ & $\begin{array}{l}\text { Four categories of resources (along } \\
\text { with the attributes of research } \\
\text { knowledge) likely to enable } \\
\text { researchers to transfer knowledge: } \\
\text { Financial } \\
\text { Organizational } \\
\text { Relational } \\
\text { Personal }\end{array}$ & $\begin{array}{l}\text { Resource-based view of the firm } \\
\text { Resource-based view of the firm- } \\
\text { researchers } \\
\text { have resources and capabilities } \\
\text { which are deployed and } \\
\text { mobilized in their knowledge } \\
\text { transfer activities } \\
\text { Reference to other included } \\
\text { frameworks } \\
\text { None }\end{array}$ & $\begin{array}{l}\text { Based on a survey of 1,554 } \\
\text { researchers, presents a model of } \\
\text { how researchers in natural sciences } \\
\text { and engineering transfer } \\
\text { knowledge outside the academic } \\
\text { community } \\
\text { Two determinants found to be } \\
\text { consistently influential: linkages } \\
\text { between researchers and research } \\
\text { users, and focus of the research } \\
\text { projects on end user needs. Other } \\
\text { determinants influencing } \\
\text { knowledge transfer varied from one } \\
\text { research field to another }\end{array}$ \\
\hline
\end{tabular}


Table 2 Conceptual frameworks relating to knowledge translation that could be used by researchers to guide their dissemination activities (Continued)

Baumbusch [51]

2008

Describe a participatory approach

to knowledge translation developed during a program of research concerning equitable care for diverse populations
Two dimensions process (translation) and content (knowledge):

Process (translation involving: credible messengers, accountability reciprocity, respect, and research champions)

Content (ongoing cycle of data collection, analysis and synthesis of knowledge)

\author{
None stated \\ Reference to other included \\ frameworks \\ Jacobson \\ Lavis
}


Table 2 Conceptual frameworks relating to knowledge translation that could be used by researchers to guide their dissemination activities (Continued)

\begin{tabular}{|c|c|}
\hline $\begin{array}{l}\text { Ward [55,56] } \\
2009 \\
\text { Reviews knowledge transfer } \\
\text { frameworks to gain a better } \\
\text { understanding of the processes } \\
\text { involved in knowledge transfer and } \\
\text { presents a five domain model of } \\
\text { the knowledge transfer processes } \\
\text { to help researchers, practitioners } \\
\text { and decision makers plan and } \\
\text { evaluate initiatives for transferring } \\
\text { knowledge into action }\end{array}$ & $\begin{array}{l}\text { Problem: Identifying and } \\
\text { communicating about the problem } \\
\text { which the knowledge needs to } \\
\text { address } \\
\text { Context: Analysing the context } \\
\text { which surrounds the producers and } \\
\text { users of knowledge } \\
\text { Knowledge: Developing and } \\
\text { selecting the knowledge to be } \\
\text { transferred } \\
\text { Intervention: Selecting specific } \\
\text { knowledge transfer activities or } \\
\text { Interventions } \\
\text { Use: Considering how the } \\
\text { knowledge will be used in practice }\end{array}$ \\
\hline
\end{tabular}

Mixed

Practical framework developed from on commonalities from 28 published models including the Diffusion of Innovations

Reference to other included frameworks

Dobbins

Greenhalgh

Jacobson

Lavis
Authors emphasise that knowledge transfer is an interactive, multidirectional rather than linear process

Report outlines a series of domain specific questions for research users and producers to use to think about and incorporate knowledge transfer processes in to their routine practice.
Innovations, adult learning, and social marketing [45]. The Practical, Robust Implementation and Sustainability Model was developed using concepts from Diffusion of Innovations, social ecology, as well as the health promotion, quality improvement, and implementation literature [52].

Three other distinct knowledge translation frameworks were included, all of which are based on a combination of literature reviews and researcher experience $[44,51,54]$.

\section{Conceptual frameworks provided by UK funders}

Of the websites of the 10 UK funders of health services and public health research, only the ESRC made a dissemination framework available to grant applicants or holders (see Table 1) [26]. A summary version of another included framework is available via the publications section of the Joseph Rowntree Foundation [60]. However, no reference is made to it in the submission guidance they make available to research applicants.

All of the UK funding bodies made brief references to dissemination in their research grant application guides. These would simply ask applicants to briefly indicate how findings arising from the research will be disseminated (often stating that this should be other than via publication in peer-reviewed journals) so as to promote or facilitate take up by users in the health services.

\section{Discussion}

This systematic scoping review presents to our knowledge the most comprehensive overview of conceptual/ organising frameworks relating to research dissemination. Thirty-three frameworks met our inclusion criteria, 20 of which were designed to be used by researchers to guide their dissemination activities. Twenty-eight included frameworks that were underpinned at least in part by one or more of three different theoretical approaches, namely persuasive communication, diffusion of innovations theory, and social marketing.

Our search strategy was deliberately broad, and we searched a number of relevant databases and other sources with no language or publication status restrictions, reducing the chance that some relevant studies were excluded from the review and of publication or language bias. However, we restricted our searches to health and social science databases, and it is possible that searches targeting for example the management or marketing literature may have revealed additional frameworks. In addition, this review was undertaken as part of a project assessing UK research dissemination, so our search for frameworks provided by funding agencies was limited to the UK. It is possible that searches of funders operating in other geographical jurisdictions may have identified other studies. We are also aware that the way in which we have defined the process of dissemination and our judgements as to what constitutes sufficient detail may have resulted in some frameworks being excluded that others may have included or vice versa. Given this, and as an aid to transparency, we have included the list of excluded papers as Additional File 2, Appendix 2 so as to allow readers to assess our, and make their own, judgements on the literature identified.

Despite these potential limitations, in this review we have identified 33 frameworks that are available and could be used to help guide dissemination planning and activity. By way of contrast, a recent systematic review of the knowledge transfer and exchange literature (with broader aims and scope) [61] identified five organising frameworks developed to guide knowledge transfer and exchange initiatives (defined as involving more than one way communications and involving genuine interaction between researchers and target audiences) [13-15,62,63]. All were identified by our searches, but only three met our specific inclusion criteria of providing sufficient 
dissemination process detail [13-15]. One reviewed methods for assessment of research utilisation in policy making [62], whilst the other reviewed knowledge mapping as a tool for understanding the many knowledge creation and translation resources and processes in a health system [63].

There is a large amount of theoretical convergence among the identified frameworks. This all the more striking given the wide range of theoretical approaches that could be applied in the context of research dissemination [64], and the relative lack of cross-referencing between the included frameworks. Three distinct but interlinked theories appear to underpin (at least in part) 28 of the included frameworks. There has been some criticism of health communications that are overly reliant on linear messenger-receiver models and do not draw upon other aspects of communication theory [65]. Although researcher focused, the included frameworks appear more participatory than simple messengerreceiver models, and there is recognition of the importance of context and emphasis on the key to successful dissemination being dependent on the need for interaction with the end user.

As we highlight in the introduction, there is recognition among international funders both of the importance of and their role in the dissemination of research [9]. Given the current political emphasis on reducing deficiencies in the uptake of knowledge about the effects of interventions into routine practice, funders could be making and advocating more systematic use of conceptual frameworks in the planning of research dissemination.

Rather than asking applicants to briefly indicate how findings arising from their proposed research will be disseminated (as seems to be the case in the UK), funding agencies could consider encouraging grant applicants to adopt a theoretically-informed approach to their research dissemination. Such an approach could be made a conditional part of any grant application process; an organising framework such as those described in this review could be used to demonstrate the rationale and understanding underpinning their proposed plans for dissemination. More systematic use of conceptual frameworks would then provide opportunities to evaluate across a range of study designs whether utilising any of the identified frameworks to guide research dissemination does in fact enhance the uptake of research findings in policy and practice.

\section{Summary}

There are currently a number of theoretically-informed frameworks available to researchers that could be used to help guide their dissemination planning and activity. Given the current emphasis on enhancing the uptake of knowledge about the effects of interventions into routine practice, funders could consider encouraging researchers to adopt a theoretically informed approach to their research dissemination.

\section{Additional material}

Additional file 1: Appendix 1: Database search strategies. This file includes details of the database specific search strategies used in the review.

Additional file 2: Appendix 2: Full-text papers assessed for eligibility but excluded from the review. This file includes details of full-text papers assessed for eligibility but excluded from the review.

\section{Acknowledgements}

This review was undertaken as part of a wider project funded by the MRC Population Health Sciences Research Network (Ref: PHSRN 11). The views expressed in this paper are those of the authors alone.

\section{Author details}

${ }^{1}$ Centre for Reviews and Dissemination, University of York, YO10 5DD, UK. ${ }^{2}$ Social and Environmental Health Department, London School of Hygiene and Tropical Medicine, WC1E 7HT, UK. ${ }^{3}$ School of Social Policy, Sociology and Social Research, University of Kent, CT2 7NF, UK. ${ }^{4} \mathrm{MRC}$ General Practice Research Framework, University College London, NW1 2ND, UK.

\section{Authors' contributions}

All authors contributed to the conception, design, and analysis of the review. All authors were involved in the writing of the first and all subsequent versions of the paper. All authors read and approved the final manuscript. Paul Wilson is the guarantor.

\section{Competing interests}

Paul Wilson is an Associate Editor of Implementation Science. All decisions on this manuscript were made by another senior editor. Paul Wilson works for, and has contributed to the development of the CRD framework which is included in this review. The author(s) declare that they have no other competing interests.

Received: 4 January 2010 Accepted: 22 November 2010 Published: 22 November 2010

\section{References}

1. Cooksey D: A review of UK health research funding. London: Stationery Office 2006.

2. Darzi A: High quality care for all: NHS next stage review final report London: Department of Health; 2008.

3. Department of Health: Best Research for Best Health: A new national health research strategy London: Department of Health; 2006.

4. National Institute for Health Research: Delivering Health Research. National Institute for Health Research Progress Report 2008/09. London: Department of Health 2009.

5. Tooke JC: Report of the High Level Group on Clinical Effectiveness A report to Sir Liam Donaldson Chief Medical Officer. London: Department of Health 2007.

6. World Health Organization: World report on knowledge for better health: strengthening health systems. Geneva: World Health Organization 2004.

7. Graham ID, Logan J, Harrison MB, Straus SE, Tetroe J, Caswell W, Robinson N: Lost in knowledge translation: time for a map? J Contin EduC Health Prof 2006, 26:13-24.

8. World Health Organization: Bridging the 'know-do' gap: meeting on knowledge translation in global health 10-12 October 2005 Geneva: World Health Organization; 2005.

9. Tetroe JM, Graham ID, Foy R, Robinson N, Eccles MP, Wensing M, Durieux P, Légaré F, Nielson CP, Adily A, Ward JE, Porter C, Shea B, Grimshaw JM: 
Health research funding agencies' support and promotion of knowledge translation: an international study. Milbank Q 2008, 86:125-55.

10. Wilson PM, Petticrew M, Calnan MW, Nazareth I: Why promote the findings of single research studies? BMJ 2008, 336:722.

11. Winkler JD, Lohr KN, Brook RH: Persuasive communication and medical technology assessment. Arch Intern Med 1985, 145:314-17.

12. Lomas J: Diffusion, Dissemination, and Implementation: Who Should Do What. Ann N Y Acad Sci 1993, 703:226-37.

13. Dobbins M, Ciliska D, Cockerill R, Barnsley J, DiCenso A: A framework for the dissemination and utilization of research for health-care policy and practice. Online J Knowl Synth Nurs 2002, 9:7.

14. Jacobson N, Butterill D, Goering P: Development of a framework for knowledge translation: understanding user context. J Health Serv Res Policy 2003, 8:94-9.

15. Lavis JN, Robertson D, Woodside JM, McLeod CB, Abelson J, Knowledge Transfer Study G: How can research organizations more effectively transfer research knowledge to decision makers? Milbank Q 2003, 81:221-48.

16. Wilson PM, Petticrew M, Calnan MW, Nazareth I: Does dissemination extend beyond publication: a survey of a cross section of public funded research in the UK. Implement Sci 2010, 5:61.

17. Centre for Reviews and Dissemination: Undertaking systematic reviews of research on effectiveness: CRD's guidance for carrying out or commissioning reviews. 3 edition. York: University of York; 2009.

18. NHS Centre for Reviews and Dissemination: Undertaking systematic reviews of research on effectiveness: CRD's guidance for carrying out or commissioning reviews. York: University of York 1994.

19. National Center for the Dissemination of Disability Research: A Review of the Literature on Dissemination and Knowledge Utilization. Austin, TX: National Center for the Dissemination of Disability Research, Southwest Educational Development Laboratory 1996.

20. Hughes M, McNeish D, Newman T, Roberts H, Sachdev D: What works? Making connections: linking research and practice. A review by Barnardo's Research and Development Team. Ifford: Barnardo's 2000.

21. Harmsworth S, Turpin S, TQEF National Co-ordination Team, Rees A, Pell G, Bridging the Gap Innovations Project: Creating an Effective Dissemination Strategy. An Expanded Interactive Workbook for Educational Development Projects. Centre for Higher Education Practice: Open University 2001.

22. Herie M, Martin GW: Knowledge diffusion in social work: a new approach to bridging the gap. Soc Work 2002, 47:85-95.

23. Scullion PA: Effective dissemination strategies. Nurse Res 2002, 10:65-77.

24. Farkas M, Jette AM, Tennstedt S, Haley SM, Quinn V: Knowledge dissemination and utilization in gerontology: an organizing framework. Gerontologist 2003, 43(Spec 1):47-56.

25. Canadian Health Services Research Foundation: Communication Notes. Developing a dissemination plan Ottawa: Canadian Health Services Research Foundation 2004.

26. Economic and Social Research Council: Communications strategy: a stepby-step guide. Swindon: Economic and Social Research Council 2004.

27. European Commission. European Research: A guide to successful communication Luxembourg: Office for Official Publications of the European Communities; 2004.

28. Carpenter D, Nieva V, Albaghal T, Sorra J: Development of a Planning Tool to Guide Dissemination of Research Results. In Advances in Patient Safety: From Research to Implementation, Programs, Tools and Practices. Volume 4. Rockville, MD: Agency for Healthcare Research and Quality; 2005.

29. Bauman AE, Nelson DE, Pratt M, Matsudo V, Schoeppe S: Dissemination of physical activity evidence, programs, policies, and surveillance in the international public health arena. Am J Prev Med 2006, 31(1 Suppl):S57-S65.

30. Formoso G, Marata AM, Magrini N: Social marketing: should it be used to promote evidence-based health information? Soc Sci Med 2007, 64:949-53.

31. Zarinpoush F, Sychowski SV, Sperling J: Effective Knowledge Transfer and Exchange: A Framework. Toronto: Imagine Canada 2007.

32. Majdzadeh R, Sadighi J, Nejat S, Mahani AS, Gholami J: Knowledge translation for research utilization: design of a knowledge translation model at Tehran University of Medical Sciences. J Contin Educ Health Prof 2008, 28:270-7.

33. Friese $B$, Bogenschneider $K$ : The voice of experience: How social scientists communicate family research to policymakers. Fam Relat 2009, 58:229-43.
34. Yuan CT, Nembhard IM, Stern AF, Brush JE Jr, Krumholz HM, Bradley EH: Blueprint for the dissemination of evidence-based practices in health care. Issue Brief (Commonw Fund) 2010, 86:1-16.

35. McGuire WJ: The nature of attitudes and attitude change. In Handbook of social psychology. Edited by: Lindzey G, Aronsen E. Reading, Mass: AddisonWesley Publishing; 1969:136-314.

36. McGuire WJ: Input and output variables currently promising for constructing persuasive communications. In Public communication campaigns.. 3 edition. Edited by: Rice R, Atkin C. Thousand Oaks, CA: Sage; 2001:22-48.

37. Lasswell HD: The structure and function of communication in society. In The communication of ideas. Edited by: Bryson L. New York: Harper and Row; 1948:37-51.

38. National Center for the Dissemination of Disability Research: Developing an Effective Dissemination Plan Austin, Tx: Southwest Educational Development Laboratory (SEDL); 2001.

39. Freemantle $N$, Watt l: Dissemination: implementing the findings of research. Health Libr Rev 1994, 11:133-7.

40. Rogers EM: The diffusion of innovations New York: Free Press; 1962.

41. Rogers EM: Diffusion of innovations. 5 edition. New York, London: Free Press; 2003.

42. Kotler P, Zaltman G: Social Marketing: An Approach to Planned Social Change. J Market 1971, 35:3-12

43. Caplan N: The two-communities theory and knowledge utilization. Am Behav Sci 1979, 22:459-70.

44. Funk SG, Tornquist EM, Champagne MT: A model for improving the dissemination of nursing research. West I Nurs Res 1989, 11:361-72.

45. Lomas J: Teaching old (and not so old) docs new tricks: effective ways to implement research findings CHEPA working paper series No 93-4. Hamiltion, Ont: McMaster University; 1993.

46. Elliott SJ, O'Loughlin J, Robinson K, Eyles J, Cameron R, Harvey D, Raine K, Gelskey D, Canadian Heart Health Dissemination Project Strategic and Research Advisory Groups: Conceptualizing dissemination research and activity: the case of the Canadian Heart Health Initiative. Health Educ Behav 2003, 30:267-82.

47. Greenhalgh T, Robert G, Bate P, Macfarlane, Kyriakidou O, Peacock R: How to spread good ideas. A systematic review of the literature on diffusion, dissemination and sustainability of innovations in health service delivery and organisation. London: National Co-ordinating Centre for NHS Service Delivery and Organisation (NCCSDO) 2004.

48. Green LW, Orleans C, Ottoson JM, Cameron R, Pierce JP, Bettinghaus EP: Inferring strategies for disseminating physical activity policies, programs, and practices from the successes of tobacco control. Am J Prev Med 2006, 31(1 Suppl):S66-S81.

49. Owen N, Glanz K, Sallis JF, Kelder SH: Evidence-based approaches to dissemination and diffusion of physical activity interventions. Am J Prev Med 2006, 31(1 Suppl):S35-S44.

50. Landry R, Amara N, Ouimet M: Determinants of Knowledge Transfer: Evidence from Canadian University Researchers in Natural Sciences and Engineering. J Technol Transfer 2007, 32:561-92.

51. Baumbusch JL, Kirkham SR, Khan KB, McDonald H, Semeniuk P, Tan E, Anderson JM: Pursuing common agendas: a collaborative model for knowledge translation between research and practice in clinical settings. Res Nurs Health 2008, 31:130-40.

52. Feldstein AC, Glasgow RE: A practical, robust implementation and sustainability model (PRISM) for integrating research findings into practice. Jt Comm J Qual Patient Saf 2008, 34:228-43.

53. Clinton M, Merritt KL, Murray SR: Using corporate universities to facilitate knowledge transfer and achieve competitive advantage: An exploratory model based on media richness and type of knowledge to be transferred. International Journal of Knowledge Management 2009, 5:43-59.

54. Mitchell P, Pirkis J, Hall J, Haas M: Partnerships for knowledge exchange in health services research, policy and practice. J Health Serv Res Policy 2009, 14:104-11.

55. Ward V, House A, Hamer S: Developing a framework for transferring knowledge into action: a thematic analysis of the literature. J Health Serv Res Policy 2009, 14:156-64.

56. Ward V, Smith S, Carruthers S, House A, Hamer S: Knowledge Brokering. Exploring the process of transferring knowledge into action Leeds: University of Leeds 2010. 
57. Greenhalgh T, Robert G, Macfarlane, Bate P, Kyriakidou O: Diffusion of innovations in service organizations: systematic review and recommendations. Millbank Q 2004, 82:581-629.

58. Wernerfelt B: A resource-based view of the firm. Strategic Manage J 1984, 5:171-80.

59. Grant R: Toward a knowledge-based theory of the firm. Strategic Manage J 1996, 17:109-22.

60. Joseph Rowntree Foundation: Findings: Linking research and practice. York: Joseph Rowntree Foundation 2000.

61. Mitton C, Adair CE, McKenzie E, Patten SB, Waye Perry B: Knowledge transfer and exchange: review and synthesis of the literature. Milbank $Q$ 2007, 85:729-68.

62. Hanney S, Gonzalez-Block M, Buxton M, Kogan M: The utilisation of health research in policy-making: concepts, examples and methods of assessment. Health Res Policy Syst 2003, 1:2.

63. Ebener S, Khan A, Shademani R, Compernolle L, Beltran M, Lansang M, Lippman M: Knowledge mapping as a technique to support knowledge translation. Bull World Health Organ 2006, 84:636-42.

64. Grol R, Bosch M, Hulscher M, Eccles M, Wensing M: Planning and studying improvement in patient care: the use of theoretical perspectives. Milbank Q 2007, 85:93-138.

65. Kuruvilla $\mathrm{S}$, Mays $\mathrm{N}$ : Reorienting health-research communication. Lancet 2005, 366:1416-18.

doi:10.1186/1748-5908-5-91

Cite this article as: Wilson et al:: Disseminating research findings: what should researchers do? A systematic scoping review of conceptual frameworks. Implementation Science 2010 5:91.

\section{Submit your next manuscript to BioMed Central} and take full advantage of:

- Convenient online submission

- Thorough peer review

- No space constraints or color figure charges

- Immediate publication on acceptance

- Inclusion in PubMed, CAS, Scopus and Google Scholar

- Research which is freely available for redistribution

Submit your manuscript at www.biomedcentral.com/submit 